\title{
Mustard bran in lactating dairy cow diets
}

\author{
H. A. Maiga, ${ }^{\star 1}$ M. L. Bauer,† C. R. Dahlen, $†$ M. Badaruddin, $\ddagger$ and E. J. Scholljegerdes $\S$ \\ *Department of Agriculture, Animal Science Division, University of Minnesota, 2900 University Ave, Crookston 56716 \\ †Department of Animal Sciences, North Dakota State University, Fargo 58108 \\ ¥Minn-Dak Growers Ltd., Grand Forks, ND 58208 \\ $\S$ The Northern Great Plains Research Laboratory USDA, Mandan, ND 58554
}

\section{ABSTRACT}

Two trials using lactating Holstein cows were conducted to evaluate effects of a diet containing oriental mustard bran on dry matter intake (DMI), milk production, milk components, and organoleptic properties. In experiment 1, 34 lactating cows (24 multiparous and 10 primiparous; days in milk $\geq 50 \mathrm{~d}$ ) were used in a switchback design to determine the lactational response and organoleptic quality of milk when the diet contained $8 \%$ oriental mustard bran (MB) versus a control diet $(\mathrm{CON})$. Mustard bran replaced a portion of soybean meal and all the beet pulp in the CON diet. Milk yields were greater for cows fed the MB diet; however, no differences were found in DMI, $3.5 \%$ fat(FCM) or solids-corrected milk. Milk components and components production were not affected by treatment. Milk organoleptic qualities were not affected by diet. In experiment 2, 22 lactating cows (16 multiparous and 6 primiparous; days in milk $\geq 21 \mathrm{~d}$ ) were assigned randomly within parity to receive $\mathrm{MB}$ or $\mathrm{CON}$ from wk 4 to 19 postpartum in a randomized complete block design. Cows were fed CON wk 1 to 3 postpartum. The MB diet contained the same ingredients as the CON, except sunflower seed and a portion of soybean meal were replaced with mustard bran. Milk and components data were collected during wk 3 postpartum and used as covariates to adjust treatment means. Intake was greater for cows fed the MB diet; however, daily milk, 3.5\% FCM, and solids-corrected milk yields were not different between diets. Milk components and component yields were not affected by treatment. Milk urea concentration was less for cows fed the MB diet. Although cows fed the MB diet had greater DMI, this was not translated into a higher milk $3.5 \% \mathrm{FCM} /$ DMI production efficiency ratio. During experiment 2, many cows fed MB experienced minor to severe hemolysis with bloody urine. This hemolysis believed to be caused by the S-methyl-cysteine sulfoxide contained in

Received October 29, 2010.

Accepted February 28, 2011.

${ }^{1}$ Corresponding author: hmaiga@umn.edu mustard bran could have affected milk production efficiency. The increased milk yield observed in experiment 1 was not observed in experiment 2. Adding $8 \%$ of $\mathrm{MB}$ to lactating cow diets had a mixed effect on DMI and milk production. Milk component yields and milk quality were not affected. Feeding this level of MB presents a hemolytic danger to lactating dairy cows.

Key words: oriental mustard bran, milk, organoleptic, lactating cow

\section{INTRODUCTION}

Brown, oriental, and yellow are the main mustard species grown in the Midwestern United States and western Canada for food and oil production. Mustard bran is the outer coat derived from the processing of the seed for mustard flour. Oriental mustard bran production is estimated to be 150 to $200 \mathrm{t}$ of bran yearly in the Midwestern United States. The chemical analysis of oriental mustard bran samples we analyzed was highly variable. Crude protein content varied from 15.5 to $21.5 \%$, crude fat from $15.5 \%$ to $20.0 \%$, and NDF from 38 to $55 \%$ of DM. Composition may also be influenced by processing methods. Processing techniques that leave more whole seed, more gluten in the bran, or both, will result in a more variable chemical composition. Despite variability in its chemical content, the nutrient profile of mustard bran makes it, a priori, an attractive alternative feed for cattle.

Early studies with mustard meal indicated it can be fed to sheep (Peterson, 1970), swine (Peterson and Danielson, 1972), beef cattle (Peterson and Thomas, 1970; Thomas, 1972), and dairy cows (Moss, 1975) with no adverse effects on DMI. Milk and milk component yields were not affected by 7.5 and $15 \%$ mustard meal in diets (Moss, 1975). To our knowledge, no studies have been conducted with feeding mustard bran to dairy cattle.

The objective of this study was to evaluate the effect of an isocaloric and isonitrogenous diet containing $8 \%$ oriental mustard bran on milk production, milk composition, DMI, and milk organoleptic quality. Because experiment 1 was a short-term study of 28 -d experimental 
periods, which may not capture true differences in DMI and production responses, experiment 2, a longer study of $16 \mathrm{wk}$, was designed to validate results found in experiment 1.

\section{MATERIALS AND METHODS}

All procedures were approved by and conducted according to the University of Minnesota Animal Care and Use Committee guidelines.

\section{Experiment 1}

Animals and Diets. Thirty-four lactating Holstein cows (24 multiparous and 10 primiparous) were paired within parity by milk production level (DIM $\geq 50 \mathrm{~d}$ ) and assigned randomly to 2 treatment diets in a switchback design of two 28-d periods, with the first $14 \mathrm{~d}$ of each period serving as adaptation to treatment and the last $14 \mathrm{~d}$ as data collection. The number of cows used was determined by the power test procedures described by McMillan (2004), based on DMI using a standard deviation of $2 \mathrm{~kg} / \mathrm{d}$. Cows were fed either the control diet $(\mathbf{C O N})$ or the oriental mustard bran-containing diet (MB) in which mustard bran replaced $26 \%$ of $\mathrm{CP}$ from soybean meal (SBM) and all of the NDF from beet pulp in the CON diet (Table 1). Diets were fed as a TMR and were formulated to contain $16 \%$ of $\mathrm{CP}$ and $1.74 \mathrm{Mcal}$ of $\mathrm{NE}_{\mathrm{L}} / \mathrm{kg}$, which called for $8 \%$ mustard bran inclusion rate in the MB diet. Because mustard bran contains $16.5 \%$ fat, TMR were also formulated to keep fat concentration below $6 \%$, which is the safe level for ruminants (Palmquist and Jenkins, 1980). Cows were housed in a tie-stall barn and fed individually a TMR once daily for ad libitum intake ( $5 \%$ orts). Amounts of feed fed and orts were recorded daily to determine DMI.

Sample Collection and Analytical Procedures. Cows were milked twice daily and milk weights were recorded at each milking during the entire experiment. Two 24-h (p.m. and a.m.) milk samples $(\sim 500 \mathrm{~mL})$ were collected during the experiment (one each week) and shipped to Stearns County DHIA laboratories (Sauk Center, MN) for analysis for fat, protein, lactose, SNF, TS, MUN, and SCC.

Milk samples ( $\sim 500 \mathrm{~mL}$, p.m. and a.m.) were also collected daily during the last $7 \mathrm{~d}$ of each treatment period for organoleptic (odor and taste) evaluation. Mustard has a special odor and contains allyl isothiocyanate which is responsible for the hot taste and might affect milk quality (Moss, 1975). A panel of 2 experienced dairy products judges and 1 beginner evaluated milk samples from 10 cows/treatment $\left(\mathrm{SCC} \leq 300 \times 10^{3} /\right.$ $\mathrm{mL}$ ). The panel scored milk odor and taste on a scale of 1 to 10 using evaluation of milk off-flavors guidelines described by Nelson and Trout (1981). A score of 1 indicates strong mustard odor or strong hot taste whereas a score of 10 indicates no defects.

Samples of TMR, corn silage, haylage, wheat straw, concentrates, and mustard bran were obtained weekly during the entire feeding period and frozen at $-20^{\circ} \mathrm{C}$. Samples were oven-dried at $55^{\circ} \mathrm{C}$ for $48 \mathrm{~h}$ and ground through a Wiley mill (1-mm screen; Arthur H. Thomas Co., Philadelphia, PA). All samples were analyzed for DM, CP, ether extract, ash, acid detergent lignin, Ca, and P (methods 934.01, 2001.11, 945.16, 942.05, 973.18, 968.08, and 965.17, respectively; AOAC, 2010). The NDF (with amylase and without sulfite) and ADF were analyzed with a fiber analysis unit (Ankom Technology, Fairport, NY) using solutions of Van Soest et al. (1991). Neutral detergent insoluble CP and acid detergent insoluble $\mathrm{CP}$ were determined by the Kjeldahl procedure (method 2001.11, AOAC, 2010) and used to calculate $\mathrm{NE}_{\mathrm{L}}(3 \times ; \mathrm{NRC}, 2001)$.

\section{Statistical Analysis}

Milk production and composition, and DMI data were subjected to ANOVA for a switchback design using generalized least squares procedures (Proc Mixed of SAS; SAS Inst., Cary, NC). The model for intake, milk production, and efficiency included fixed effects of parity, period, treatment, interactions, and day within period was a repeated variable. Covariance structures were first-order autoregressive, compound symmetry, or unstructured, whichever minimized fit statistics. The model for milk components and component production

Table 1. Ingredient composition of TMR for cows fed the control $(\mathrm{CON})$ or the oriental mustard bran $(\mathrm{MB})$ diets in experiment 1

\begin{tabular}{|c|c|c|}
\hline \multirow[b]{2}{*}{ Item, $\%$ of DM } & \multicolumn{2}{|c|}{ Diet } \\
\hline & $\mathrm{CON}$ & $\mathrm{MB}$ \\
\hline Alfalfa haylage & 26.7 & 25.5 \\
\hline Corn silage & 26.8 & 25.5 \\
\hline Wheat straw & 1.0 & 1.0 \\
\hline High-moisture corn (26\% DM) & 21.0 & 20.6 \\
\hline Soybean meal $(46 \% \mathrm{CP})$ & 11.0 & 9.0 \\
\hline $\mathrm{MB}$ & - & 7.9 \\
\hline Sunflower seed & 3.0 & 3.0 \\
\hline Dried corn distillers grains & 5.7 & 5.7 \\
\hline Dried beet pulp & 3.0 & - \\
\hline Dicalcium phosphate $\left(\mathrm{CaHPO}_{4}\right)$ & 0.30 & 0.30 \\
\hline Sodium bicarbonate $\left(\mathrm{NaHCO}_{3}\right)$ & 0.75 & 0.75 \\
\hline Trace-mineralized salt ${ }^{1}$ & 0.60 & 0.60 \\
\hline Vitamin $\mathrm{ADE}^{2}$ & 0.15 & 0.15 \\
\hline
\end{tabular}

${ }^{1}$ Provided per kilogram of diet DM: $36.5 \mathrm{mg}$ of Zn; $26 \mathrm{mg}$ of Mn; 20.5 $\mathrm{mg}$ of $\mathrm{Fe} ; 9.1 \mathrm{mg}$ of $\mathrm{Cu} ; 0.60 \mathrm{mg}$ of I; $0.4 \mathrm{mg}$ of Co; and $0.3 \mathrm{mg}$ of Se. ${ }^{2}$ Provided per kilogram of diet DM: 6,875 IU of supplemental vitamin A; 1,379 IU of supplemental vitamin D; and 23 IU of supplemental vitamin $\mathrm{E}$. 
Table 2. Ingredient composition of TMR for cows fed the control $(\mathrm{CON})$ or the oriental mustard bran (MB) diets in experiment 2

\begin{tabular}{|c|c|c|}
\hline \multirow[b]{2}{*}{ Item, $\%$ of DM } & \multicolumn{2}{|c|}{ Diet } \\
\hline & $\mathrm{CON}$ & $\mathrm{MB}$ \\
\hline Alfalfa haylage & 24.5 & 23.5 \\
\hline Corn silage & 24.5 & 23.5 \\
\hline Straw, wheat & 3.2 & 2.8 \\
\hline High-moisture shelled corn & 21.5 & 21.5 \\
\hline Soybean meal & 12.2 & 9.4 \\
\hline $\mathrm{MB}$ & - & 8.0 \\
\hline Sunflower seed & 2.8 & - \\
\hline Dried corn distillers grains & 8.7 & 8.7 \\
\hline Dicalcium phosphate $\left(\mathrm{CaHPO}_{4}\right)$ & 0.29 & 0.29 \\
\hline Sodium bicarbonate $\left(\mathrm{NaHCO}_{3}\right)$ & 1.00 & 1.00 \\
\hline Calcium carbonate $\left(\mathrm{CaCO}_{3}\right)$ & 0.50 & 0.50 \\
\hline Trace-mineralized salt $^{1}$ & 0.60 & 0.60 \\
\hline Vitamin $\mathrm{ADE}^{2}$ & 0.21 & 0.21 \\
\hline
\end{tabular}

${ }^{1}$ Provided per kilogram of diet DM: $36.5 \mathrm{mg}$ of $\mathrm{Zn} ; 26 \mathrm{mg}$ of Mn; 20.5 $\mathrm{mg}$ of $\mathrm{Fe} ; 9.1 \mathrm{mg}$ of $\mathrm{Cu}$; $0.60 \mathrm{mg}$ of I; $0.4 \mathrm{mg}$ of $\mathrm{Co}$; and $0.3 \mathrm{mg}$ of Se. ${ }^{2}$ Provided per kilogram of diet DM: 6,875 IU of supplemental vitamin A; 1,379 IU of supplemental vitamin D; and 23 IU of supplemental vitamin E.

only included fixed effects of parity, period, treatment, and interactions. The model for organoleptic data comprised the fixed effect of treatment and random effect of juror.

\section{Experiment 2}

Animals and Diets. Twenty-two lactating Holstein cows (16 multiparous and 6 primiparous; DIM $\geq 21 \mathrm{~d}$ ) were assigned randomly within parity to receive a diet containing $8 \% \mathrm{MB}$ or $\mathrm{CON}$, from wk 4 to 19 postpartum in a randomized complete block design. The num- ber of cows used was determined as in experiment 1 . The CON diet was made of corn silage, alfalfa haylage, wheat straw, and the concentrate portion containing rolled high-moisture corn, SBM, sunflower seed, dried distillers grains, minerals, and vitamins. The MB diet contained the same ingredients as the CON, except sunflower seed and a portion of SBM were replaced with mustard bran from the same source as in experiment 1 (Table 2). Diets were formulated as in experiment 1 to be isocaloric, and isonitrogenous, and to contain $8 \%$ MB.

Cows were housed in the same tie-stall barn as in experiment 1 and fed individually a TMR once daily for ad libitum intake (5\% orts). Cows were fed the CON diet during the pre-treatment period (calving to wk 3 postpartum) then switched to treatment diets after collection of pretreatment milk samples and recording of milk weights. Cows were fed experimental diets from wk 4 through 19 postpartum. Amounts of feed fed and orts were recorded daily to determine DMI.

Sample Collection and Analytical Procedures. Cows were milked twice daily and milk weights were recorded at each milking during the entire experiment. Two 24-h (p.m. and a.m.) milk samples $(\sim 500 \mathrm{~mL})$ were collected from each cow during wk 3 postpartum (before they were fed the experimental diets), and one 24-h (p.m. and a.m.) milk sample was taken weekly throughout the experiment. Milk samples were analyzed for fat, protein, lactose, SNF, MUN, and SCC, as described previously in experiment 1 . Frozen samples were also shipped to the Northern Great Plains Research Laboratory USDA (Mandan, ND) for fatty acid analysis via direct transesterification (Whitney et al.,

Table 3. Chemical composition of forages, mustard bran (MB), and control (CON) and oriental MB diets fed in experiment 1

\begin{tabular}{|c|c|c|c|c|c|c|}
\hline \multirow[b]{2}{*}{ Item } & \multicolumn{3}{|c|}{ Forage } & \multirow[b]{2}{*}{ MB } & \multicolumn{2}{|c|}{ Diet } \\
\hline & $\begin{array}{c}\text { Alfalfa } \\
\text { haylage }\end{array}$ & $\begin{array}{l}\text { Corn } \\
\text { silage }\end{array}$ & $\begin{array}{l}\text { Wheat } \\
\text { straw }\end{array}$ & & $\mathrm{CON}$ & MB \\
\hline $\mathrm{DM}, \%$ & 43.2 & 38.3 & 90.0 & 94.5 & 53.1 & 54.3 \\
\hline \multicolumn{7}{|l|}{ Chemical composition, DM basis } \\
\hline $\mathrm{CP}, \%$ & 19.5 & 7.3 & 3.6 & 17.5 & 16.4 & 16.3 \\
\hline $\mathrm{NE}_{\mathrm{L}},{ }^{1} \mathrm{Mcal} / \mathrm{kg}$ & 1.43 & 1.72 & 0.97 & 1.73 & 1.74 & 1.74 \\
\hline Ether extract, \% & 2.4 & 3.0 & 1.8 & 16.5 & 4.1 & 5.2 \\
\hline NDF, \% & 42.3 & 38.9 & 85.0 & 44.5 & 31.0 & 32.7 \\
\hline $\mathrm{ADF}, \%$ & 30.8 & 19.0 & 54.0 & 31.3 & 18.0 & 18.8 \\
\hline Lignin, \% & 7.3 & 2.2 & 6.5 & 5.1 & 3.1 & 3.5 \\
\hline $\mathrm{NFC}^{2} \%$ & 25.8 & 46.7 & 1.8 & 41.5 & 41.7 & 39.5 \\
\hline Starch, ${ }^{3} \%$ & - & - & - & - & 28.9 & 27.8 \\
\hline Ash, $\%$ & 10.0 & 4.1 & 7.8 & 4.9 & 7.0 & 6.6 \\
\hline $\mathrm{Ca}, \%$ & 1.55 & 0.21 & 0.18 & 1.19 & 0.73 & 0.69 \\
\hline $\mathrm{P}, \%$ & 0.50 & 0.27 & 0.05 & 0.34 & 0.43 & 0.40 \\
\hline $\mathrm{Mg}, \%$ & 0.36 & 0.24 & 0.12 & 0.24 & 0.29 & 0.29 \\
\hline
\end{tabular}

${ }^{1}$ Calculated using $3 \times$ maintenance $\mathrm{NE}_{\mathrm{L}}$ equation from $\mathrm{NRC}(2001)$.

${ }^{2} \mathrm{NFC}=100-(\% \mathrm{NDF}+\% \mathrm{CP}+\%$ ether extract $+\%$ ash $)$ according to the NRC (2001) model.

${ }^{3}$ Estimated for TMR only using Spartan Dairy program of Michigan State University (East Lansing). 
Table 4. Intake, milk production and composition, and organoleptic quality of milk for cows fed control $(\mathrm{CON})$ and oriental mustard bran $(\mathrm{MB})$ diets in experiment 1

\begin{tabular}{|c|c|c|c|c|}
\hline \multirow[b]{2}{*}{ Item } & \multicolumn{2}{|c|}{ Diet } & \multirow[b]{2}{*}{ SEM } & \multirow[b]{2}{*}{$P$-value } \\
\hline & $\mathrm{CON}$ & $\mathrm{MB}$ & & \\
\hline Cows, $\mathrm{n}$ & 34 & 34 & & \\
\hline DMI, kg/d & 22.3 & 22.7 & 0.56 & 0.65 \\
\hline \multicolumn{5}{|l|}{ Milk production } \\
\hline Milk, $\mathrm{kg} / \mathrm{d}$ & 38.8 & 42.0 & 0.97 & 0.04 \\
\hline $3.5 \% \mathrm{FCM}^{1}{ }^{1} \mathrm{~kg} / \mathrm{d}$ & 40.6 & 41.0 & 0.96 & 0.72 \\
\hline $\mathrm{SCM}^{2}{ }^{2} \mathrm{~kg} / \mathrm{d}$ & 35.0 & 35.5 & 0.83 & 0.70 \\
\hline \multicolumn{5}{|l|}{ Milk component } \\
\hline Fat, $\%$ & 3.45 & 3.37 & 0.07 & 0.44 \\
\hline Protein, \% & 2.87 & 2.86 & 0.04 & 0.85 \\
\hline Lactose, \% & 4.89 & 4.89 & 0.03 & 0.90 \\
\hline $\mathrm{SNF}, \%$ & 7.76 & 7.74 & 0.05 & 0.82 \\
\hline $\mathrm{TS}, \%$ & 11.21 & 11.12 & 0.11 & 0.52 \\
\hline Urea, $\mathrm{m} M$ & 13.31 & 12.91 & 0.31 & 0.35 \\
\hline $\mathrm{SCC}, \times 10^{3} / \mathrm{mL}$ & 385 & 315 & 108 & 0.65 \\
\hline \multicolumn{5}{|c|}{ Milk component production } \\
\hline Fat, $\mathrm{kg} / \mathrm{d}$ & 1.41 & 1.41 & 0.04 & 0.99 \\
\hline Protein, kg/d & 1.17 & 1.20 & 0.03 & 0.47 \\
\hline Lactose, $\mathrm{kg} / \mathrm{d}$ & 2.00 & 2.05 & 0.05 & 0.44 \\
\hline $\mathrm{SNF}, \mathrm{kg} / \mathrm{d}$ & 3.17 & 3.25 & 0.07 & 0.42 \\
\hline $\mathrm{TS}, \mathrm{kg} / \mathrm{d}$ & 4.58 & 4.66 & 0.10 & 0.58 \\
\hline \multicolumn{5}{|c|}{ Milk production efficiency } \\
\hline $3.5 \%$ FCM $/ \mathrm{DMI}$ & 1.78 & 1.80 & 0.05 & 0.74 \\
\hline \multicolumn{5}{|c|}{ Organoleptic evaluation $^{3}$} \\
\hline Taste & 9.57 & 9.81 & 0.16 & 0.07 \\
\hline Off flavor & 9.74 & 9.89 & 0.08 & 0.08 \\
\hline
\end{tabular}

${ }^{1} 3.5 \% \mathrm{FCM}=(0.432 \times \mathrm{kg} / \mathrm{d}$ of milk $)+(16.23 \times \mathrm{kg} / \mathrm{d}$ of fat $)$ (Britt et al., 2003$)$.

${ }^{2} \mathrm{SCM}=(12.3 \times \mathrm{kg} / \mathrm{d}$ of fat $)+(6.56 \times \mathrm{kg} / \mathrm{d}$ of SNF $)-(0.0752 \times \mathrm{kg} / \mathrm{d}$ of milk) (Tyrrell and Reid, 1965).

${ }^{3}$ Scored on a scale of 1 to 10 . Score of 1 means strong mustard odor or strong hot taste, and score of $10=$ no noticeable defect.

1999) with an alkaline catalyst (KOH), as described by Murrieta et al. (2003). Separation of fatty acid methyl esters was achieved by GLC (Model CP-3800; Varian, Inc., Palo Alto, CA) with a $100 \mathrm{~m} \times 0.25 \mathrm{~mm}$ (i.d.) $\times 0.2 \mu \mathrm{m}$ (film thickness) capillary column (SP-2560, Supelco, Bellefonte, PA) and $\mathrm{H}_{2}$ gas as the carrier at 1.5 $\mathrm{mL} / \mathrm{min}$. The initial oven temperature was maintained at $120^{\circ} \mathrm{C}$ for $2 \mathrm{~min}$, increased to $210^{\circ} \mathrm{C}$ at $6^{\circ} \mathrm{C} / \mathrm{min}$, and then increased to $250^{\circ} \mathrm{C}$ at $5^{\circ} \mathrm{C} / \mathrm{min}$. The injector temperature was $260^{\circ} \mathrm{C}$ and the flame ionization detector temperature was $300^{\circ} \mathrm{C}$. Identification of peaks was accomplished using purified fatty acid standards (Sigma-Aldrich, St. Louis, MO; Nu-Chek Prep, Elysian, MN; Matreya, Pleasant Gap, PA). One milligram of methyl tridecanoic acid (13:0) was used as an internal standard.

Samples of TMR, corn silage, haylage, wheat straw, concentrates, and mustard bran were obtained weekly during the entire feeding period and frozen at $-20^{\circ} \mathrm{C}$. Samples were oven-dried at $55^{\circ} \mathrm{C}$ for $48 \mathrm{~h}$ and ground through an ultracentrifuge mill (1-mm screen; Brinkmann Instrument Co., Westbury, NY). All samples were analyzed for DM, CP, ether extract, ash, NDF, $\mathrm{ADF}$, acid detergent lignin, $\mathrm{Ca}$, and $\mathrm{P}$ content as in experiment 1. Mustard bran samples were shipped to Olson Station Biochemistry Laboratory (South Dakota State University, Brookings, SD) for AA content determination. Amino acid content was analyzed by methods 988.15 and 994.12 AOAC (2010). Also, samples of MB were sent to the Experiment Station Chemical Laboratory (University of Missouri-Columbia) for fatty acid analysis by the AOAC (2010) method 972.28. In vitro DM digestibility of MB was determined by the modified 2-stage technique of Tilly and Terry (1963) as described by Holden (1999). The NDF digestibility was estimated after a single-stage, 48-h in vitro incubation.

\section{Statistical Analysis}

Data of milk production and composition obtained from wk 4 to 19 were adjusted using wk 3 data as covariates if $P \leq 0.15$. All data were subjected to ANOVA for a randomized complete block design using generalized least squares (Proc Mixed of SAS). The model included treatment, parity, and their interaction. Day was a repeated variable for milk production, intake, and milk production efficiency (3.5\% FCM/DMI). Week was a repeated variable for milk components and component 
Table 5. Chemical composition of forages, mustard bran (MB), TMR control (CON), TMR MB diets fed in experiment 2

\begin{tabular}{|c|c|c|c|c|c|c|}
\hline \multirow[b]{2}{*}{ Item } & \multicolumn{3}{|c|}{ Forage } & \multirow[b]{2}{*}{ MB } & \multicolumn{2}{|c|}{ Diet } \\
\hline & $\begin{array}{c}\text { Alfalfa } \\
\text { haylage }\end{array}$ & $\begin{array}{l}\text { Corn } \\
\text { silage }\end{array}$ & $\begin{array}{l}\text { Wheat } \\
\text { straw }\end{array}$ & & $\mathrm{CON}$ & MB \\
\hline $\mathrm{DM}, \%$ & 48.5 & 39.0 & 90.0 & 92.8 & 56.8 & 58.1 \\
\hline \multicolumn{7}{|l|}{ Chemical composition, DM basis } \\
\hline $\mathrm{CP}, \%$ & 19.3 & 7.3 & 3.6 & 21.0 & 17.4 & 17.2 \\
\hline $\mathrm{NE}_{\mathrm{L}},{ }^{1} \mathrm{Mcal} / \mathrm{kg}$ & 1.34 & 1.50 & 0.97 & 2.36 & 1.74 & 1.74 \\
\hline Ether extract, \% & 2.8 & 3.5 & 1.8 & 20.8 & 4.9 & 5.2 \\
\hline NDF, $\%$ & 39.6 & 41.5 & 85.0 & 36.0 & 29.1 & 29.6 \\
\hline $\mathrm{ADF}, \%$ & 30.6 & 22.9 & 54.0 & 23.4 & 17.4 & 17.7 \\
\hline Lignin, \% & 7.31 & 2.34 & 10.0 & 5.1 & 3.8 & 3.8 \\
\hline $\mathrm{NFC}^{2} \%$ & 31.1 & 43.5 & 1.8 & 18.4 & 41.9 & 41.5 \\
\hline Ash, \% & 7.3 & 4.2 & 7.8 & 4.8 & 6.7 & 6.6 \\
\hline $\mathrm{Ca}, \%$ & 1.52 & 0.17 & 0.18 & 0.92 & 0.87 & 0.89 \\
\hline $\mathrm{P}, \%$ & 0.21 & 0.21 & 0.05 & 0.45 & 0.44 & 0.44 \\
\hline $\mathrm{Mg}, \%$ & 0.35 & 0.23 & 0.12 & 0.26 & 0.29 & 0.29 \\
\hline
\end{tabular}

${ }^{1}$ Calculated using $3 \times$ maintenance $\mathrm{NE}_{\mathrm{L}}$ equation from NRC (2001).

${ }^{2} \mathrm{NFC}=100-(\% \mathrm{NDF}+\% \mathrm{CP}+\%$ ether extract $+\%$ ash $)$ according to the NRC (2001) model.

production. Covariance structures were first-order autoregressive, first-order ante dependence, compound symmetry, or unstructured, whichever minimized fit statistics.

\section{RESULTS AND DISCUSSION}

\section{Experiment 1}

Nutrient Content of Diets. The chemical composition of forages, oriental mustard bran, and experimental diets is presented in Table 3. Crude protein, ADF, and calculated $\mathrm{NE}_{\mathrm{L}}(3 \times)$ content of diets were similar between diets. The NDF percentage was slightly higher in the MB diet because of the high fiber content of the MB but this NDF is highly digestible (see discussion for experiment 2). Ether extract content was higher for the MB diet because of the high fat content of MB.

DMI, Milk Yield, and Composition. Daily DMI (Table 4) for cows fed CON and MB diets were not different $(P=0.65)$. Feeding $7.5 \%$ mustard meal did not affect DMI (Moss, 1975). Peterson (1970), as quoted by Moss (1975), observed no palatability problems when lambs or beef heifers were fed protein supplements containing $20 \%$ mustard meal. Like the mustard meal studies, our results show that mustard bran did not affect intake or apparent palatability. The allyl isothiocyanate contained in mustard (Moss 1975) did not adversely affect DMI of cows fed the MB diet. Daily milk production of cows fed $\mathrm{MB}$ diet was greater $(P$ $=0.04)$ than that of cows fed the CON diet. However, $3.5 \% \mathrm{FCM}$ and SCM yields were not affected $(P \geq$ $0.70)$ by diets. This is because milk fat production from cows fed the CON diet was not different $(P=0.99)$ but offset the greater milk yield of cows fed the MB diet. A high milk production from feeding the MB diet could possibly be explained in the short-term by a better energetic utilization of this diet. The concentrations of milk fat, protein, lactose, SNF, TS, urea, SCC, and milk production efficiency ( $3.5 \% \mathrm{FCM}, \mathrm{kg} / \mathrm{kg}$ of DMI) were not different between treatments $(P \geq 0.35)$. In addition, daily production of milk fat, protein, lactose, SNF, and TS were not different between treatments $(P$ $\geq 0.42$ ). Milk yield, milk fat, SNF, and milk protein

Table 6. Amino acid composition of oriental mustard bran fed in experiment 2

\begin{tabular}{lccc}
\hline & \multicolumn{3}{c}{ Basis } \\
\cline { 2 - 4 } Item & $\mathrm{DM}^{1}$ & $\mathrm{CP}^{2}$ & EAA $^{3}$ \\
\hline CP, \% & 21.4 & - & - \\
AA & & & \\
Alanine, \% & 0.79 & 3.69 & - \\
Arginine, \% & 1.06 & 4.95 & 12.97 \\
Aspartic acid, \% & 1.37 & 6.40 & - \\
Cystine, \% & 0.56 & 2.62 & - \\
Glutamic acid, \% & 2.92 & 13.64 & - \\
Glycine, \% & 0.99 & 4.63 & - \\
Histidine, \% & 0.45 & 2.10 & 5.51 \\
Isoleucine, \% & 0.78 & 3.64 & 9.55 \\
Leucine, \% & 1.23 & 5.75 & 15.06 \\
Lysine, \% & 1.36 & 6.36 & 16.65 \\
Methionine, \% & 0.31 & 1.45 & 3.79 \\
Phenylalanine, \% & 0.75 & 3.50 & 9.18 \\
Proline, \% & 1.55 & 7.24 & - \\
Serine, \% & 0.92 & 4.30 & - \\
Threonine, \% & 0.97 & 4.53 & 11.87 \\
Tryptophan, \% & 0.20 & 0.93 & 2.45 \\
Valine, \% & 1.06 & 4.95 & 12.97 \\
TEAA & 8.17 & 38.18 & -
\end{tabular}

${ }^{1} \mathrm{AA}$ as a percent of DM.

${ }^{2} \mathrm{AA}$ as a percent of $\mathrm{CP}$.

${ }^{3}$ Essential AA as a percent of total EAA.

${ }^{4}$ Total EAA. 
Table 7. Fatty acid composition (\% of total fatty acids) of oriental mustard bran (MB), control diet (CON), and MB diet in experiment 2

\begin{tabular}{lrrr}
\hline & & \multicolumn{2}{c}{ TMR } \\
\cline { 3 - 4 } Fatty acid & MB & CON & MB \\
\hline $14: 0$ & 0.09 & 0.35 & 0.35 \\
$14: 1$ & 0.00 & 0.25 & 0.20 \\
$15: 0$ & 0.00 & 0.07 & 0.07 \\
$16: 0$ & 4.28 & 17.04 & 15.83 \\
$16: 1$ & 0.65 & 0.26 & 0.47 \\
$17: 0$ & 0.00 & 0.10 & 0.11 \\
$18: 0$ & 1.72 & 3.70 & 3.15 \\
$18: 1$ trans-9 & 0.19 & 0.00 & 0.00 \\
$18: 1$ n-9 & 19.53 & 42.31 & 28.85 \\
$18: 1$ n-7 & 3.59 & 1.08 & 2.22 \\
$18: 2$ & 23.46 & 53.27 & 49.90 \\
$18: 3$ & 10.34 & 8.58 & 10.08 \\
$18: 4$ & 0.00 & 0.13 & 0.12 \\
$20: 0$ & 1.00 & 0.74 & 0.93 \\
$20: 2$ & 1.13 & 0.00 & 0.44 \\
$20: 1$ n-9 & 11.04 & 0.87 & 4.26 \\
$20: 3$ trans-3 & 0.24 & 0.00 & 0.00 \\
$22: 0$ & 0.64 & 0.94 & 0.85 \\
$22: 1$ n-9 & 23.17 & 0.94 & 7.90 \\
$22: 2$ n-6 & 0.59 & 0.56 & 0.64 \\
$24: 0$ & 0.53 & 1.27 & 1.21 \\
$24: 1$ n-9 & 1.69 & 0.07 & 0.63 \\
\hline
\end{tabular}

were not affected when mustard meal was fed to dairy cows (Moss, 1975).

Organoleptic Evaluation. No taste or odor differences $(P \geq 0.07)$ of milk from cows fed the CON or the MB diets were observed (Table 4 ). The taste panel was unable to differentiate milk from cows fed the CON diet or the MB diet. No objectionable taste or offensive odors of any of the milk samples were detected. Similar observations were reported by Moss (1975) when mustard meal was feed to lactating Holstein cows.

\section{Experiment 2}

Nutrient Content of Diets. The chemical composition of forages, MB, and TMR is presented in Table 5 . The chemical content of experimental diets was similar. The AA composition of MB is presented in Table 6 . Concentrations of essential AA as percentages of DM were lower compared with those of SBM; however, as percentages of $\mathrm{CP}$, lysine, and methionine were very close to those of SBM (NRC, 2001). This AA makeup would complement corn protein in a corn-based diet well. The fatty acid composition of $\mathrm{MB}$ and TMR is presented in Table 7 . The fatty acid content of the MB diet was greater for cis-vaccenic (18:1 n-7), linolenic (18:3 n-3), arachidic (20:1 n-9), and erucic (22:1 n-9) acids than those of the CON diet. Brassicas are known to contain high level of erucic acid (DePeters and Bath, 1986). The oleic (18:1 n-9) and linoleic (18:2) content was much greater in the CON than in the MB diet. The high linoleic acid in the CON diet was due to sunflower seed, which has higher linoleic acid (68.6\%) content (Peng et al., 2010) than does MB (23.46\%). The MB had an in vitro DM digestibility of $66.8 \%$ and an in vitro NDF digestibility of $81.6 \%$.

DMI, Milk Yield, and Composition. During experiment 2, many cows fed the MB diet experienced minor to severe hemolysis with bloody urine. Four firstlactation cows, with severe hemolysis that appeared after wk 4 of the experiment, were removed from the experiment and replaced by new cows of same parity and similar production level. Three older cows and one first-lactation cow with minor hemolysis were kept in the study; however, they appeared not to be cured from the hemolysis over the feeding period. Brassicas contain S-methyl-cysteine sulfoxide (Gustine, 1985; Fales et al. 1987; Lambert et al. 1987), which is converted by rumen microorganisms to the toxic S-methyl cysteine dimethyl disulfide. This disulfide was shown to cause hemolytic anemia in cattle and sheep (Gustine, 1985). The nature of the hemolysis described by Gustine (1985) is very similar to the one observed in experiment 2 .

In the short-term switchback study (experiment 1) with 28-d feeding periods, cows did not show any apparent sign of hemolysis. In the long term study (experiment 2), cows did not show hemolysis until after $4 \mathrm{wk}$ in the experiment. The lack of hemolysis in cows used in the short-term study could be because of insufficient exposure and conversion rate of S-methyl cysteine sulfoxide to the toxic dimethyl disulfide. The level of S-methyl-cysteine sulfoxide in the MB and its conversion rate to its toxic form in the rumen is not known. We consulted with several analytical laboratories and were unable to find one that was currently measuring S-methyl-cysteine sulfoxide.

Dry matter intake was greater $(P=0.03)$ for cows fed the MB diet (Table 8); however, intake interacted $(P=0.004)$ with parity, where multiparous cows fed $\mathrm{MB}$ ate more feed than did cows fed CON and primiparous cows were not different (Table 9). However, in experiment $1, \mathrm{MB}$ did not affect DMI. No palatability problem was observed with mustard meal diets fed to ruminants (Peterson, 1970), swine (Peterson and Danielson, 1972), beef cattle (Peterson and Thomas, 1970; Thomas, 1972), and dairy cows (Moss, 1975). Mustard is in the family of brassicas (e.g., rapeseed, turnip, cabbage, radish, kale, and cauliflower). Brassicas contain toxic or anti-nutritional factors such as erucic acid (DePeters and Bath, 1986), and glucosinolate (Bell, 1984; Fales et al. 1987; Maesoomi et al. 2006), precursors of thiocyanate goitrogenic compounds. A high DMI intake of the MB diet over the CON diet is an indication that the MB diet was palatable and apparently the anti-nutritional factors of mustard reported in these 
Table 8. Intake and milk composition for lactating dairy cows fed control (CON) and oriental mustard bran (MB) diets in experiment 2

\begin{tabular}{|c|c|c|c|c|c|}
\hline \multirow[b]{2}{*}{ Item } & \multicolumn{2}{|c|}{ Treatment (Trt) } & \multirow[b]{2}{*}{ SEM } & \multicolumn{2}{|c|}{$P$-value } \\
\hline & $\mathrm{CON}$ & MB & & Trt & $\begin{array}{c}\text { Trt } \\
\times \text { parity }\end{array}$ \\
\hline Cows, n & 11 & 11 & & & \\
\hline DMI, $\mathrm{kg} / \mathrm{d}$ & 20.4 & 22.0 & 0.50 & 0.03 & 0.004 \\
\hline \multicolumn{6}{|l|}{ Milk production } \\
\hline Milk, ${ }^{1} \mathrm{~kg} / \mathrm{d}$ & 41.0 & 41.8 & 0.82 & 0.48 & 0.007 \\
\hline $3.5 \% \mathrm{FCM}^{1,2} \mathrm{~kg} / \mathrm{d}$ & 42.8 & 43.5 & 1.6 & 0.76 & 0.17 \\
\hline $\mathrm{SCM},{ }^{1,3} \mathrm{~kg} / \mathrm{d}$ & 39.4 & 39.9 & 1.5 & 0.81 & 0.23 \\
\hline \multicolumn{6}{|l|}{ Milk component } \\
\hline Fat, \% & 3.87 & 3.85 & 0.12 & 0.85 & 0.49 \\
\hline Protein. ${ }^{1} \%$ & 2.92 & 2.87 & 0.02 & 0.12 & 0.55 \\
\hline Lactose, ${ }^{1} \%$ & 4.86 & 4.89 & 0.02 & 0.26 & 0.006 \\
\hline $\mathrm{SNF}, 1 \%$ & 8.79 & 8.74 & 0.04 & 0.40 & 0.07 \\
\hline $\mathrm{TS},{ }^{1} \%$ & 12.61 & 12.55 & 0.13 & 0.73 & 0.22 \\
\hline Urea, ${ }^{1} \mathrm{~m} M$ & 17.42 & 15.52 & 0.33 & $<0.001$ & 0.05 \\
\hline $\mathrm{SCC},{ }^{1} \times 10^{3} / \mathrm{mL}$ & 427 & 348 & 76 & 0.46 & 0.19 \\
\hline \multicolumn{6}{|c|}{ Milk component production } \\
\hline Fat, ${ }^{1} \mathrm{~kg} / \mathrm{d}$ & 1.56 & 1.58 & 0.07 & 0.84 & 0.25 \\
\hline Protein, ${ }^{1} \mathrm{~kg} / \mathrm{d}$ & 1.21 & 1.20 & 0.05 & 0.90 & 0.27 \\
\hline Lactose, ${ }^{1} \mathrm{~kg} / \mathrm{d}$ & 2.06 & 2.10 & 0.05 & 0.51 & 0.29 \\
\hline $\mathrm{SNF},{ }^{1} \mathrm{~kg} / \mathrm{d}$ & 3.73 & 3.86 & 0.10 & 0.33 & 0.32 \\
\hline $\mathrm{TS},{ }^{1} \mathrm{~kg} / \mathrm{d}$ & 5.09 & 5.16 & 0.20 & 0.81 & 0.25 \\
\hline \multicolumn{6}{|c|}{ Milk production efficiency } \\
\hline $3.5 \% \mathrm{FCM} / \mathrm{DMI}$ & 2.1 & 1.98 & 0.14 & 0.53 & 0.86 \\
\hline
\end{tabular}

studies did not interfere with DMI. Daily milk production and milk components were not different $(P \geq 0.12)$ between diets (Table 8$)$; however, an interaction $(P \leq$ $0.05)$ with parity for milk production, milk lactose concentration, and milk urea concentration was observed (Table 9). Multiparous cows fed MB produced more milk than CON, whereas no difference existed between primiparous heifers. The increase in milk produced by multiparous cows consuming MB appears to be related to their increased intake. However, in experiment 1 , cows produced more milk and intake was not different. Concentration of lactose was greatest for primiparous cows among the 4 parity-treatment groups. This change was small and is likely to be of little biological importance. Urea concentration was less for multiparous cows fed MB than CON and no treatment differences were apparent within primiparous cows. The concentrations of milk fat, protein, TS, and SCC were not affected $(P$ $\geq 0.12$ ) by diet, which is in agreement with experiment 1 data. The $3.5 \%$ FCM production efficiency ratio was not different between treatments (2.01 vs. $1.98 \mathrm{~kg}$ of $3.5 \% \mathrm{FCM} / \mathrm{kg}$ of DMI for CON and $\mathrm{MB}$, respectively).

The fatty acid profile of milk fat was altered by MB (Table 10). The proportion of monounsaturated fatty acids was increased $(P=0.02)$ in the milk from cows fed the MB diet due primarily to more C18:1 cis-6 (petroselenic), C18:1 trans-11 (vaccenic), and C22:1 (erucic). Vaccenic acid has anticarcinogenic effect in human foods, mediated through its conversion to rumenic acid [cis-9, trans-11 conjugated linoleic acid

Table 9. Intake and milk composition for the interaction between treatment and parity $(\mathrm{T} \times \mathrm{P})$ for lactating dairy cows fed control $(\mathrm{CON})$ and oriental mustard bran (MB) diets in experiment 2

\begin{tabular}{|c|c|c|c|c|c|c|c|c|}
\hline Item & \multicolumn{2}{|c|}{ Heifer } & \multicolumn{2}{|c|}{ Cow } & $\mathrm{SEM}^{1}$ & \multicolumn{3}{|c|}{$P$-value } \\
\hline DMI, $\mathrm{kg} / \mathrm{d}$ & 19.0 & 18.3 & 21.8 & 25.8 & 0.86 & 0.03 & $<0.001$ & 0.004 \\
\hline Milk, $\mathrm{kg} / \mathrm{d}$ & 39.8 & 37.2 & 42.2 & 46.3 & 1.49 & 0.82 & 0.001 & 0.007 \\
\hline Lactose, \% & 4.85 & 4.96 & 4.88 & 4.82 & 0.03 & 0.26 & 0.08 & 0.006 \\
\hline $\mathrm{SNF}, \%$ & 8.83 & 8.89 & 8.76 & 8.60 & 0.08 & 0.40 & 0.02 & 0.07 \\
\hline
\end{tabular}

${ }^{1} \mathrm{SEM}$ associated with an $\mathrm{n}$ of 3 . 
Table 10. Effect of mustard bran on fatty acid composition of milk in experiment 2

\begin{tabular}{|c|c|c|c|c|}
\hline \multirow[b]{2}{*}{$\begin{array}{l}\text { Fatty acid, } \\
\mathrm{g} / 100 \mathrm{~g} \text { of fatty acid }\end{array}$} & \multicolumn{2}{|c|}{ Treatment } & \multirow[b]{2}{*}{ SEM } & \multirow[b]{2}{*}{$P$-value } \\
\hline & Control & $\begin{array}{l}\text { Mustard } \\
\text { bran }\end{array}$ & & \\
\hline 4:0 & 1.59 & 1.64 & 0.04 & 0.45 \\
\hline 8:0 & 1.10 & 1.16 & 0.04 & 0.32 \\
\hline 10:0 & 2.33 & 2.36 & 0.17 & 0.88 \\
\hline 11:0 & 0.27 & 0.27 & 0.01 & 0.81 \\
\hline $12: 0$ & 3.08 & 3.17 & 0.15 & 0.67 \\
\hline $14: 0^{1}$ & 11.09 & 10.86 & 0.34 & 0.63 \\
\hline $14: 1^{1}$ & 0.79 & 0.77 & 0.04 & 0.83 \\
\hline 15:0 & 1.05 & 0.99 & 0.03 & 0.22 \\
\hline $16: 0^{1}$ & 24.35 & 23.17 & 0.78 & 0.28 \\
\hline $16: 1$ cis $^{1}$ & 1.55 & 1.47 & 0.06 & 0.34 \\
\hline 16:1 trans & 0.32 & 0.34 & 0.02 & 0.53 \\
\hline $17: 0^{1}$ & 0.55 & 0.56 & 0.01 & 0.50 \\
\hline $17: 1^{1}$ & 0.16 & 0.18 & 0.01 & 0.24 \\
\hline $18: 0$ & 12.35 & 12.01 & 0.52 & 0.65 \\
\hline $18: 1$ cis- 6 & 0.31 & 0.72 & 0.10 & 0.01 \\
\hline 18:1 n-9 cis $^{1}$ & 24.37 & 24.39 & 0.72 & 0.98 \\
\hline 18:1 cis-11 & 0.68 & 0.70 & 0.02 & 0.12 \\
\hline $18: 1$ trans $-11^{1}$ & 3.01 & 3.50 & 0.08 & $<0.001$ \\
\hline $18: 2 \mathrm{n}-6$ cis $^{1}$ & 2.75 & 2.98 & 0.05 & 0.006 \\
\hline $18: 2 \mathrm{n}-6$ trans & 0.30 & 0.30 & 0.01 & 0.82 \\
\hline $18: 2$ cis- 9 trans- $11^{1}$ & 0.66 & 0.65 & 0.05 & 0.88 \\
\hline $18: 2$ trans -10, cis $-12^{1}$ & 0.002 & 0.009 & 0.001 & 0.001 \\
\hline $18: 3 n-3$ & 0.015 & 0.023 & 0.002 & $<0.0001$ \\
\hline $18: 3$ n-6 & 0.34 & 0.51 & 0.01 & 0.03 \\
\hline $20: 0$ & 0.14 & 0.39 & 0.01 & $<0.001$ \\
\hline $20: 4$ n-6 & 0.13 & 0.13 & 0.01 & 0.88 \\
\hline $22: 0^{1}$ & 0.054 & 0.110 & 0.002 & $<0.001$ \\
\hline $22: 1 \mathrm{n}-9^{1}$ & 0.01 & 0.23 & 0.01 & $<0.001$ \\
\hline Saturated $^{1}$ & 58.41 & 57.66 & 1.14 & 0.63 \\
\hline Monounsaturated $^{1}$ & 35.33 & 37.46 & 0.57 & 0.02 \\
\hline Polyunsaturated ${ }^{1}$ & 4.65 & 4.92 & 0.17 & 0.27 \\
\hline$n-3^{1}$ & 0.42 & 0.57 & 0.02 & $<0.001$ \\
\hline$n-6^{1}$ & 3.50 & 3.71 & 0.10 & 0.16 \\
\hline Total, mg/g of DM & 318 & 323 & 13 & 0.80 \\
\hline
\end{tabular}

${ }^{1}$ Pretrial measures were used as covariates $(P \leq 0.15)$.

(CLA)] (Lock et al., 2004). Erucic acid is believed not to have a nutritional value (DePeters and Bath, 1986). The proportion of one CLA isomer (C18:2, trans-10, cis-12) was increased $(P<0.001)$. The increase in milk C18:2 trans-10, cis-12, a potent inhibitor of milk fat synthesis (McGuire and McGuire, 2000; Bauman and Griinari, 2003), was not great enough to suppress milk fat synthesis in cows fed the MB diet. The rumenic acid, reported to be the only CLA shown unequivocally to inhibit carcinogenesis in experimental animals (Kelly et al., 1998), was not changed by diet. The proportion of $\alpha$-linolenic acid (C18:3 n-3), and gamma-linolenic acid $(\mathrm{C} 18: 3 \mathrm{n}-6)$ was increased $(P \leq 0.03)$ by the MB diet. The n-3 fatty acids were also increased $(P<0.001)$ in the milk of cows fed the MB diet, which are believed to have an anticarcinogenic effect in human diets (Gleissman et al., 2010). Diets did not affect $(P \geq 0.37)$ the proportion of short-, medium-, or long-chain fatty acids (data not shown). Changes in fatty acids profile did not affect milk fat percentage and yield.

\section{CONCLUSIONS}

In experiment 1 , adding $8 \% \mathrm{MB}$ to lactating cow diets increased daily milk production by $3.2 \mathrm{~kg}$, but did not affect DMI, percentages and production of milk fat, protein, lactose, SNF, and TS, or urea N or SCC. Milk organoleptic qualities (odor and taste) were not affected by feeding MB to dairy cattle. In experiment 2 , feeding a diet containing $8 \%$ of MB to lactating cows increased DMI only in multiparous cows, with corresponding changes in milk production; however, component yields were not affected by feeding MB. But MB presents some danger of hemolysis to lactating dairy cows. Future studies could explore safe levels of MB and S-methyl cysteine sulfoxide in dairy cattle diets, and further investigate nutrient digestibility of MB.

\section{ACKNOWLEDGMENTS}

The authors gratefully acknowledge the livestock crew at Northwest Research and Outreach Center 
(Crookston, MN) for care of the cows and for assistance with collection data.

\section{REFERENCES}

AOAC. 2010. Official Methods of Analysis. 18th ed., 3rd rev. Association of Official Analytical Chemists International, Gaithersburg, MD.

Bauman, D. E., and J. M. Griinari. 2003. Nutritional regulation of milk fat synthesis. Annu. Rev. Nutr. 23:203-227.

Bell, J. M. 1984. Nutrients and toxicants in rapeseed meal: A review. J. Anim. Sci. 58:996-1010.

Britt, J. S., R. C. Thomas, N. C. Speer, and M. B. Hall. 2003. Efficiency of converting nutrient dry matter to milk in Holstein herds. J. Dairy Sci. 86:3796-3801.

DePeters, E. J., and D. L. Bath. 1986. Canola meal versus cottonseed meal as the protein supplement in dairy diets. J. Dairy Sci. 69:148-154.

Fales, S. L., D. L. Gustine, S. C. Bosworth, and R. J. Hoover. 1987. Concentrations of glucosinolates and S-methyl cysteine sulfoxide in ensiled rape (Brassica napus L.). J. Dairy Sci. 70:2402-2405.

Gleissman, H., J. I. Johnsen, and P. Kogner. 2010. Omega-3 fatty acids in cancer, the protectors of good and the killers of evil? Exp. Cell Res. 316:1365-1373

Gustine, L. D. 1985. Determination of S-methyl cysteine sulfoxide in brassica extracts by high-performance liquid chromatography. J Chromatogr. 319:450-453.

Holden, L. A. 1999. Comparison of methods of in vitro dry matter digestibility for ten feeds. J. Dairy Sci. 82:1791-1794.

Kelly, M. L., J. R. Berry, D. A. Dwyer, J. M. Griinari, P. Y. Chouinard, M. E. Van Amburgh, and D. E. Bauman. 1998. Dietary fatty acid sources affect conjugated linoleic acid concentrations in milk from lactating dairy cows. J. Nutr. 128:881-885.

Lambert, M. G., S. M. Abrams, H. W. Harpster, and G. A. Jung. 1987. Effects of hay substitution on intake and digestibility of forage rape (Brassica napus) fed to lambs. J. Anim. Sci. 65:1639-1646.

Lock, A. L., B. A. Corl, D. M. Barbano, D. E. Bauman, and C. Ip. 2004. The anticarcinogenic effect of trans-11 18:1 is dependent on its conversion to cis-9, trans-11 CLA by $\Delta 9$-desaturase in rats. J. Nutr. 134:2698-2704.

Maesoomi, S. M., G. R. Ghorbani, M. Alikhani, and A. Nikkhah. 2006. Short communication: Canola meal as a substitute for cottonseed meal in diet of midlactation Holsteins. J. Dairy Sci. 89:1673-1677.
McGuire, M. A., and M. K. McGuire. 2000. Conjugated linoleic (CLA): A ruminant fatty acid with beneficial effects on human health. J. Anim. Sci. 77:1-8.

McMillan, I. 2004. Designing trials to test the bioequivalence of diets for animal performance. J. Anim. Sci. 82(E. Suppl.):E223-E228.

Moss, B. R. 1975. Mustard meal in dairy rations. J. Dairy Sci $58: 1682-1687$

Murrieta, C. M., B. W. Hess, and D. C. Rule. 2003. Comparison of acidic and alkaline catalysts for preparation of fatty acid methyl esters from ovine muscle with emphasis on conjugated linoleic acid. Meat Sci. 65:523-529.

Nelson, J. A., and G. M. Trout. 1981. Judging Dairy Products. 4th rev. ed. AVI Publ. Co., Inc., Westport, CT.

NRC. 2001. Nutrient Requirements of Dairy Cattle. 7th rev. ed. Natl. Acad. Sci., Washington DC.

Palmquist, D. L., and T. C. Jenkins. 1980. Fat in lactation rations: Review. J. Dairy Sci. 63:1-14

Peng, Y. S., M. A. Brown, J. P. Wu, and Z. Liu. 2010. Different oilseed supplements alter fatty acid composition of different adipose tissues of adult ewes. Meat Sci. 85:542-549.

Peterson, H. L. 1970. Evaluation of mustard meal as a source of supplemental protein. MS Thesis. Montana State University, Bozeman, MT.

Peterson, H. L., and D. M. Danielson. 1972. Mustard meal diets for growing-finishing swine. Pages 586-590 in Proc. West. Sect. Am. Soc. Anim. Sci. 23. West. Sect., Am. Soc. Anim. Sci., Champaign, IL.

Peterson, H. L., and O. O. Thomas. 1970. Mustard meal as protein source for ruminants. Pages 117-122 in Proc. West. Sect. Am. Soc. Anim. Sci. 21. West. Sect., Am. Soc. Anim. Sci., Champaign, IL.

Thomas, O. O. 1972. Mustard meal in wintering and fattening rations for beef cattle. Proc. 23rd MT Nutr. Conf., MT Agric. Exp. Sta. Res. Report 16. Montana State Univ., Bozeman.

Tilly, J. M. A., and R. A. Terry. 1963. A two-stage technique for the in vitro digestion of forage crops. J. Br. Grassl. Soc. 18:104-111.

Tyrrell, H. F., and J. T. Reid. 1965. Prediction of the energy value of cow's milk. J. Dairy Sci. 48:1215-1223.

Van Soest, P. J., J. B. Robertson, and B. A. Levis. 1991. Methods for dietary fiber, neutral detergent fiber, and nonstructural polysaccharides in relation to animal nutrition. J. Dairy Sci. 74:35833597.

Whitney, M. B., B. W. Hess, J. E. Kaltenbach, H. J. Harlow, and D. C. Rule. 1999. Direct transesterification of lipids from feedstuffs and ruminal bacteria. Can. J. Anim. Sci. 79:247-249. 